ISSN 2080-1653

DOI 10.24917/20801653.341.7

\author{
TETIANA YEMCHUK \\ Chernivtsi Yurii Fedkovych National University, Chernivtsi, Ukraine \\ OKSANA ARPUL \\ National University of Food Technologies, Kyiv, Ukraine
}

\title{
Competitive Positions in Restaurant Business in Present-Day Conditions Based on the Example of Chernivtsi (Ukraine)
}

\begin{abstract}
Intensification of competition in restaurant business is accompanied by the emergence of a large number of competing dining establishments in both domestic and foreign markets, the increase of market requirements that force restaurants to continuously develop their strategic potentials, seek for various options for their effective work and create new competitive advantages. Availability of such advantages in restaurant industry is among the most important preconditions to obtain the surplus and develop business, which determines the relevance of the present research. Thus, the present study is aimed at demonstrating the ways of helping an increase of the competitiveness and efficiency in public catering establishments in present-day conditions of economic management. The authors discuss the concept of competitive advantages, analyse the results of the assessment of restaurant competitiveness (60 restaurants of Chernivtsi have been assessed), and suggest criteria to help rank the restaurant-type establishments of Chernivtsi by indicators of their competitiveness. The company's total rating combines all important parameters (indicators) of financial and economic activity, marketing, investment, production activities, etc. Rating of competitiveness makes it possible to see which the best restaurants are, as well as to determine further goals and steps for those who gained fewer points. These goals and steps include: efficient use of available potential; definition and expansion of the range of products; up-to-date serving; development and introduction of new forms of service; development of customer-oriented complex of restaurant services based on the study of customers' habits; increase of staff competitiveness; reduction of restaurant expenses; attraction of new customers by way of modern advertising campaigns, etc.
\end{abstract}

Keywords: competitive positions; ranking score of competitiveness; restaurant business

Received: 13 June 2019

Accepted: 29 December 2019

\section{Suggested citation:}

Yemchuk, T., Arpul, O. (2020). Competitive Positions in Restaurant Business in Present-Day Conditions Based on the Example of Chernivtsi (Ukraine). Prace Komisji Geografii Przemysłu Polskiego Towarzystwa Geograficznego [Studies of the Industrial Geography Commission of the Polish Geographical Society], 34(1), 92-107. doi: 10.24917/20801653.341.7 


\section{INTRODUCTION}

Competition in restaurant business aggravates with the arrival of big number of competitive establishments of public catering. Situation causes restaurants to reveal their strategic potentials, seek for such potentials' most efficient use, and create new competitive positions. Availability of such positions in restaurant business is among the key elements to get profits, let restaurants survive and develop in present-day environment. All these issues constitute the rationale of the present study. Restaurants manifesting stable competitive positions of their own have the best chances in comparison to other players on the market.

Analysing publications where problems of competitive positions are discussed, we conclude that this category is complex and multifaceted, as well as there exists differential system of concept semantics' interpretation. The majority of researchers considers competitive positions from the point of view of the consumer and regards them as some specificity that brings essential profit or benefit leaning toward the idea that these positions should base on consumer value. However, the present-day literature gives no clear definition of the aforesaid concept. The problems of competitiveness were revealed in the works of various researchers. M. Porter in his Competitive Advantage of Nations (1990) has developed the theory of competitive positions where competitiveness was defined as the ability to compete in the global market with availability of global strategy. According to M. Porter, competitiveness predefines the country's success or failure in specific sectors of production, and sets its place in the system of world economics, while domestic competitiveness is defined by the industry's ability to continuously develop and introduce innovations (Ivanov, 2008).

Jean-Jacques Lambin (2004) presented his own definitions and interpretations of competitive positions accentuating upon external and internal competitive positions.

A. Smith was the first in the history of economic sciences who spoke of the leading role of competition in functioning of market economics, and thus founded the bases of present-day theory of competition. D. Ricardo's contribution was essential in the formulation of the essence and the role of free competition which now serves as a basis for modern elaborations in the theory of perfect competition.

Problems of competitiveness and competitive positions were also highlighted in the works by national scientists where we would accentuate on the studies by T.O. Zagorna, O. Sushko (2005), P. Smoleniuk, T.V. Androsova, N.O. Vlasova, N.V. Mykhailovam et al. (2010). The ways to raise competitiveness of the company in conditions of globalisation were discussed in a number of works by M.D. Davydova (2011).

A company should implement competitiveness and position itself in a favourable manner or at least protect its situation in order to succeed with deep consideration of the threat of available and new entrant competitors (Porter, 1980; Güngören, Orhan, 2001; Ormanidhi, Siringa, 2008).

A company should identify its place in the market and compete against threats to its position (Tavitiyaman, Quand Zhang, 2011; Covin, Slevin, 1990).

Restaurants are important generators of income in many countries. Thus, it is vitally important to determine what specific competitive positions would an establishment of restaurant business manifest and keep to (Voon, 2012; Omar, Ariffin, Ahmad, 2016), since no method can take into account the whole scope of sector specificities in 
restaurant economy, and the problem solution therefore requires a deeper analysis and is individual for every single establishment.

The majority of scientists engaged in problems of competitiveness do not discern between types of public catering establishments depending on the specificity of their activity. This is why the questions of some aspects of restaurant competitiveness are still insufficiently studied and need introduction of competitiveness ranking criteria which would allow for the disclosure of highly competitive restaurants and see what additional measures are needed to help low-competitive restaurants. Basing on the examples of the Chernivtsi restaurants, the present study aimed at demonstrating the ways of helping increase the competitiveness and efficiency in public catering establishments in present-day conditions of economic management.

\section{RESEARCH CONDITIONS}

A big number of different-type establishments of public catering that realize their broad or narrow assortment of products in a homogeneous segment of the market, as well as relatively free entrance in the market and exit from it allow for the conclusion that these establishments work in conditions of perfect competition (Androsova et al., 2010)

According to a definition given at the European Forum for Quality Management, competitiveness of a company represents its real and potential opportunities in its present conditions to develop, produce and realise goods that appear to be more attractive than the competitor's if their price and non-price merits are taken into account (Dolzhanskyi, 2006).

Specific nature of competition in restaurant business is connected with functions characteristic for industrial enterprises when the latter manufacture, realize and organize the consumption of their products. Combination of functions of production and non-production spheres preconditions complicacy of the subject of competition in public catering establishments. Unlike in many other sectors of industry where the subject of competition is represented by production, works or services, competitiveness of economic entity in restaurant business depends on the competitiveness of both the product and the offered services. It should be noted that, in present-day conditions of development of national economics, services are more and more often regarded as a way to enrich the value of a single company in consumer's eyes and thus provide for the company's competitiveness within a certain period of time. However, unlike in many other sectors, the provision of services and organisation of serving in restaurant business stand out as integral components and are inseparably apprehended by the consumer when he is served the offered company's product. Thus, on the one hand, performance in the way of an industrial company, that is, being made to produce, realise and organise the consumption of its own products, significantly broadens the field for competition in restaurant business, while on the other hand it witnesses difficulties in provision of competitiveness since it requires the consideration of all components of restaurant activity which also includes the establishment's atmosphere, cleanness, comfort, personnel's competence and care.

Restaurant business in present-day market conditions is characterised as one of the most dynamic sectors of national economy. Market makes restaurants not only produce qualitative products and realise them but take measures to help reduce the product's 
first cost and increase the consumers' demands. A catering establishment should possess such a spectrum of competitive positions which would provide for being one step ahead in its specialisation (Pshhenyshniuk, 2012). And solution of this problem needs some number of new theoretical and applied developments directed to formation of restaurant's competitive positions and its competition strategy.

Broadly speaking, in the characterisation of the essence of the concept of "restaurant's competitive positions", we should emphasize that such positions represent combinations of all restaurant's available resources (primary, spatial, labour, managerial, technological, information, marketing, etc), and such ways of their use that would provide for wider capacities to produce and realise goods and services in comparison to competitors. That is, competitive positions represent in the first turn a system of key factors that differentiate the restaurant from its competitors and add to provision of its stable leadership in the market within a certain period of time.

Sources that form competitive positions in restaurant business are represented by qualified labour, favourable conditions for production, creation of new products and introduction of innovations, essential reduction of first cost, product's high quality, unique and optimal assortment that fits visitors' demands, regulation of establishment's own prices, high levels of social responsibility and serving.

The principal task of restaurant industry is defined by the concept of hospitability determined as satisfying the customer's most particular wishes, for, if guests did not find enjoyment in visiting a restaurant, no other thing matters. Organisation of catering does not provide for satisfaction of only gastronomic demands, but for rest and entertainment, i.e., satisfaction of socio-cultural demands.

A restaurant's success today to a great extent depends on the availability of wellthought-out management, up-to-date cuisine, restaurant's concept, faultless provision of services, interesting interior and reasonable prices. Modern restaurants gain their competitive positions introducing innovations such as restaurant's new design, new process of production, new approaches to marketing, new methods of qualifications upgrade, etc. The quality of services in restaurant business is dictated by customers' demands and predominantly defined by the scope, the type and the character of services provided to guests. The factors that effect on the quality of services include convenience of accessibility, precise choice of working hours, quality of the cuisine, high technological level of production, hygienic safety (observance of sanitary-technical requirements to maintenance of premises, utensils and furniture), comfortableness of halls, personnel qualifications (cooks' skills, personnel's carefulness, politeness and obligingness to guests, qualitative management, and service rate), availability of efficient marketing and sales strategies (Table 1).

As appears from the aforesaid, the restaurant's competitive positions are regarded as a mechanism to help form conditions necessary for the most complete and multi-sided use of those specificities of the establishment that positively differ from those of the competitors, which in the short run provide for the increase of restaurant's efficiency, and in the long run - for its survival realised through continuous search for new opportunities and quick adaptation to surrounding market environment and ever-changing conditions of competitive struggle. 
Table 1. Elements of restaurant competitiveness

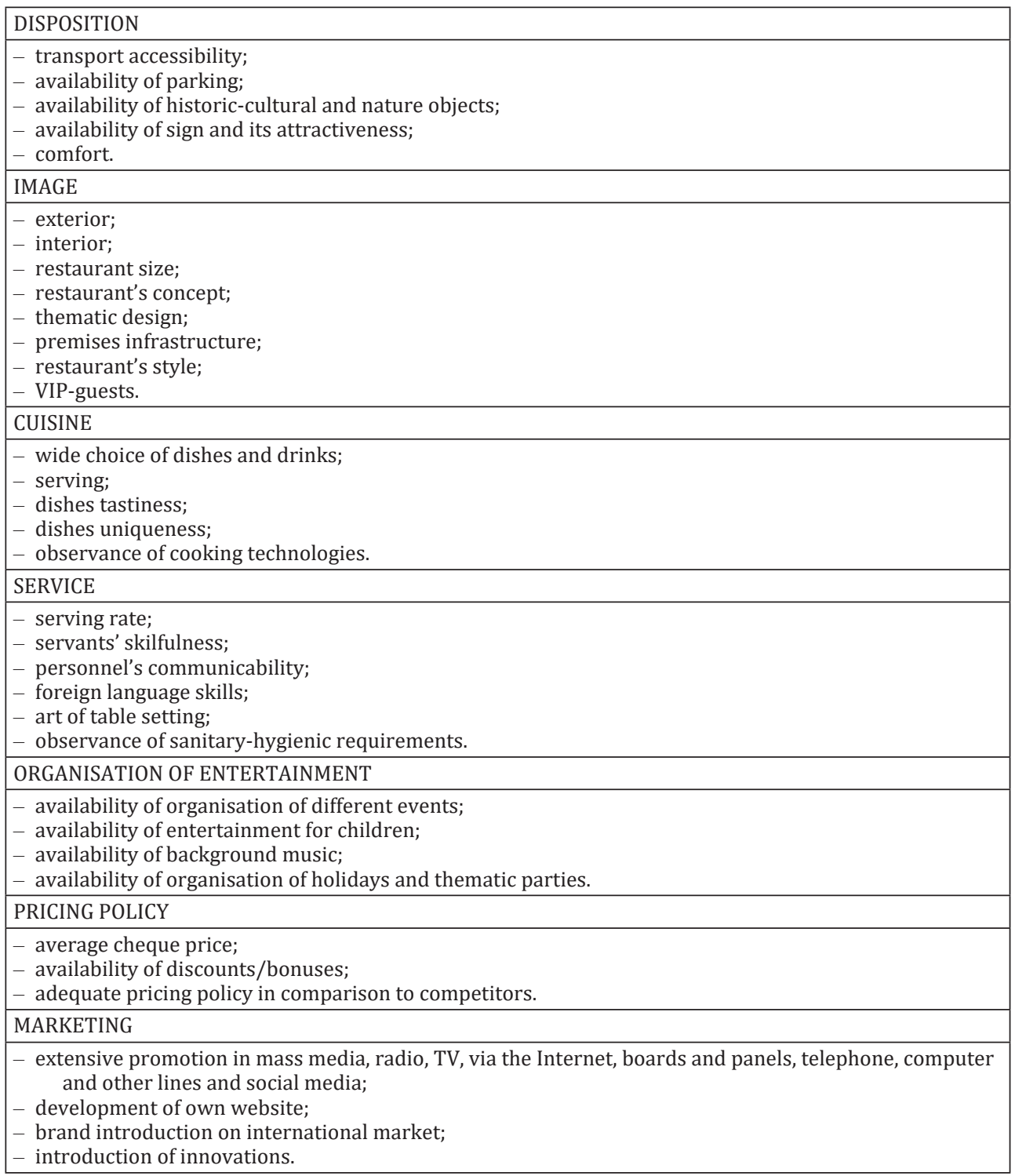

Source: authors' own work

\section{Methodology}

Fundamentals of the theory of competitiveness, sources that help form competitive advantages in restaurant business, conceptual approaches of national and world scientists to complex study of assessment of competitiveness and ascertainment of the level of restaurant competitiveness were used as methodological bases of this research.

The present work based on geo-spatial, systems-structural and conceptual approaches. In the process of study the authors relied on the principles of scientificalness 
(to form scientific postulates), objectivity (to objectively disclose the study problem), practicality (possibility of application of study results in realisation of practical goals and tasks), and integrity (to help ascertain interlinks between different components of the elements of competitiveness).

Multidimensionality of phenomena, processes and factors analysed in this work has preconditioned the necessity of application of a number of general and specific scientific methods, where we have made use of those of analysis and synthesis, causeand-effect relationship, typology, systems approach, modelling, abstracting and specification, use of literary, statistical and other sources. With regard to specific scientific methods, we have applied comparative-geographic (disclosure of common and different features of Chernivtsi restaurants' competitiveness in different places of the city), point-based (to define the degree of restaurant competitiveness), geo-informational (to highlight information on restaurants' of Chernivtsi activity; develop cartographic models (polygon of competitiveness), typificational (to outline competitive groups of restaurant-type establishments of Chernivtsi), and ranking (to distinguish between restaurants-leaders and restaurants-outsiders).

Assessment of competitiveness of restaurant business takes into account all essential parameters and figures of financial, economic, marketing, investment, production, etc. activities. We have suggested a number of criteria that would be helpful in the evaluation of competitive positions in restaurant business, namely: 1) establishment's geographical disposition; 2) availability of historic-cultural or known natural monuments; 3) availability of parking zone; 4) establishment's exterior; 5) establishment's interior; 6) establishment's cuisine; 7) quality of services; 8) availability of entertainment measures; 9) availability of entertainment and amusements for children; 10) average cheque price per individual; 11) provision of additional services; 12) system of restaurant's marketing and promotion.

A point-based scale is introduced for more precise qualitative assessment of each of 12 criteria of restaurant competitiveness (Table 2). We believe that the use of 6-point assessment scale (from 0 to 5 points) would be utmost helpful in determination of criteria that manifest most influential competitiveness. Bitter rivalry in restaurant business and essential importance of non-price means of competitive struggle made us suggest the 0-point called to According to data available with the Nielsen research company as of September 2017, there were 10,994 establishments functioning in the area of public catering in 6 biggest cities of Ukraine (Kyiv, Lviv, Odesa, Kharkiv, Zaporizhzhia and Dnipro) where restaurants and cafes constituting 46\% (5,009 entities). The establishments of the FastFood category had the share of $40 \%(4,427$ entities), while bars, pubs and night clubs totalled 14\% (1,558 entities) more hardly assess competitiveness of catering enterprises.

Competing restaurants are appropriated points upon their comparative analysis and consequential establishment of their competitive positions. The maximum possible gain within the competitiveness criteria is 5 , and 0 is minimal. The maximum possible total gain amounts to 60 points, whereas 0 points makes minimal possible value.

Commonly, the biggest number of points can be gained by restaurants with convenient geographical disposition, excellent exterior and interior, broad menu and wide assortment of additional measures, while those providing the least spectrum of services will "enjoy" the outsider's position. 


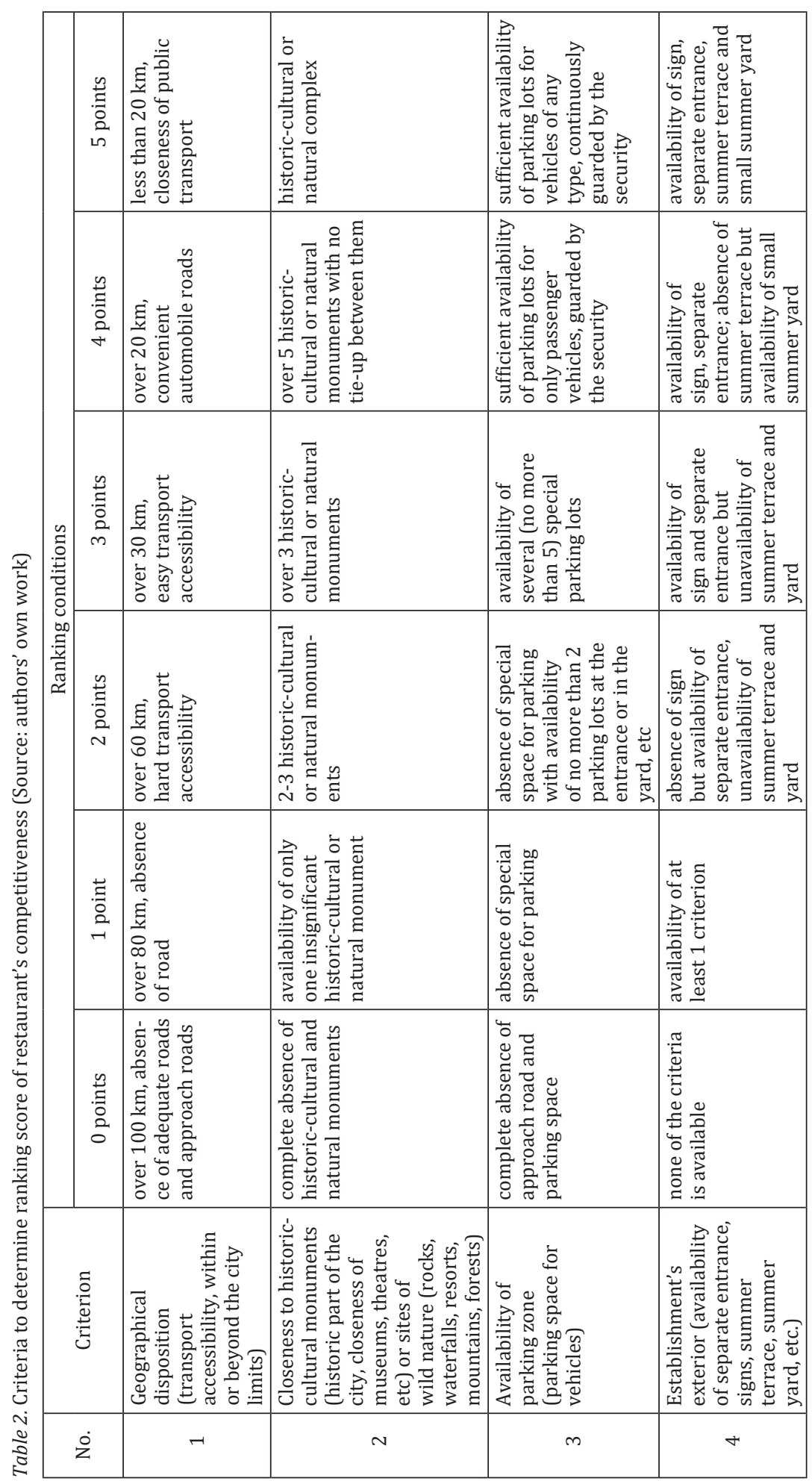




\begin{tabular}{|c|c|c|c|}
\hline 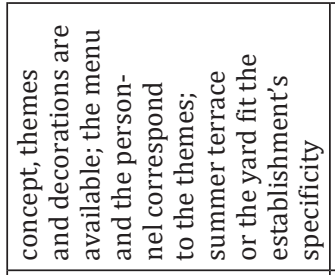 & 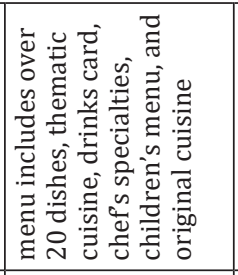 & 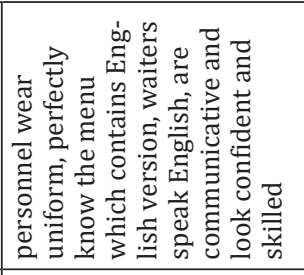 & 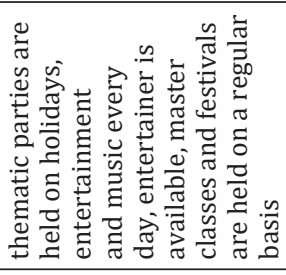 \\
\hline 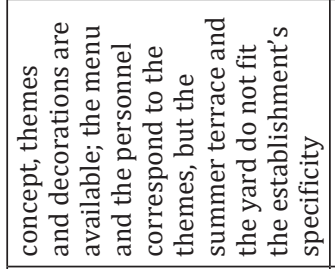 & 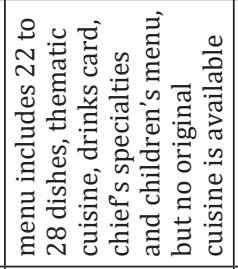 & 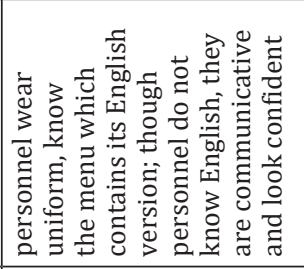 & 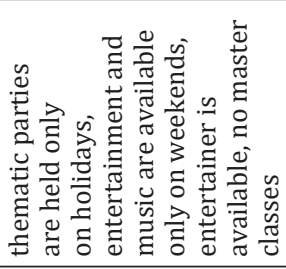 \\
\hline 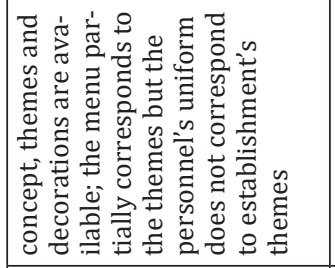 & 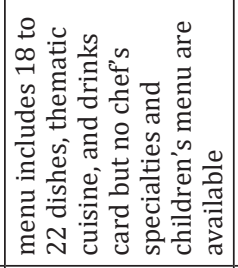 & 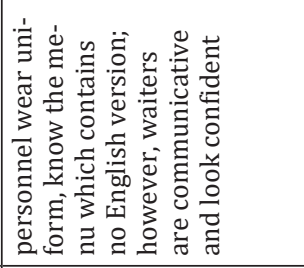 & 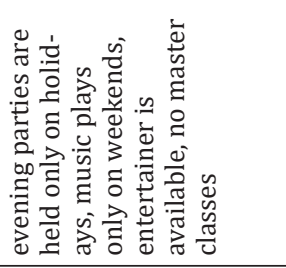 \\
\hline 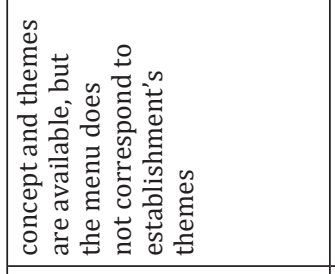 & 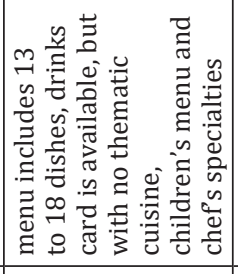 & 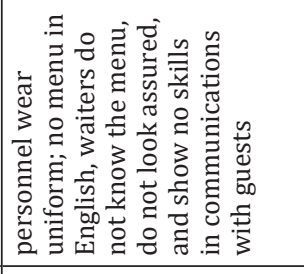 & 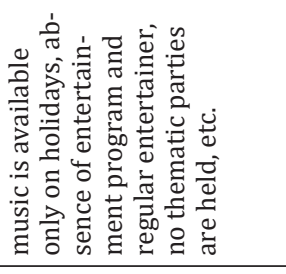 \\
\hline 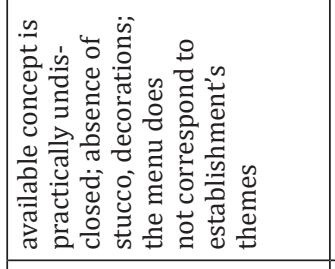 & 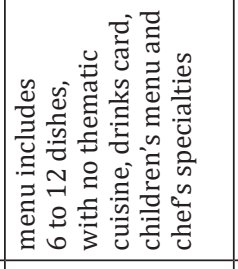 & 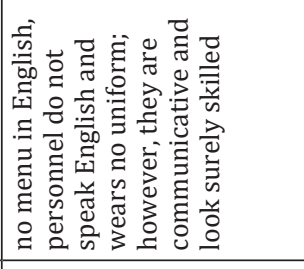 & 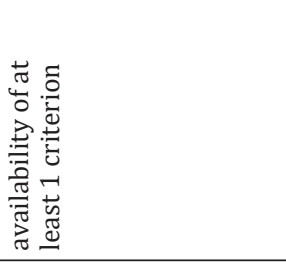 \\
\hline 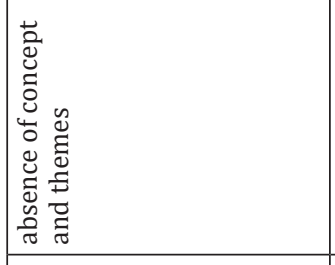 & 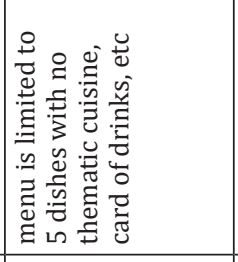 & 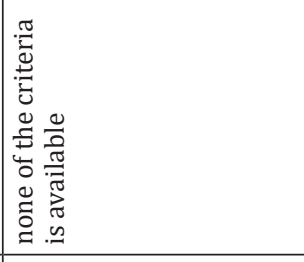 & 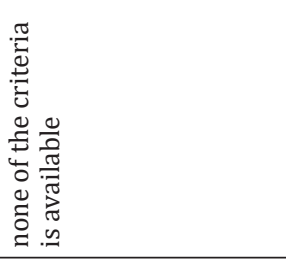 \\
\hline 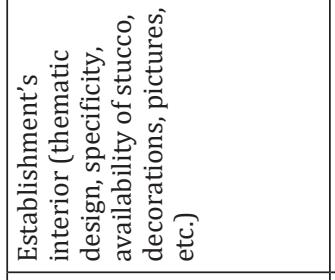 & 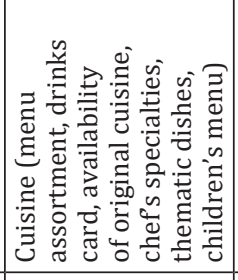 & 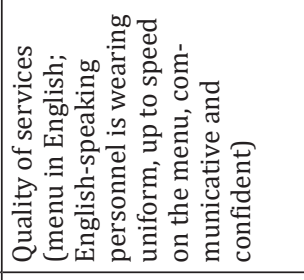 & 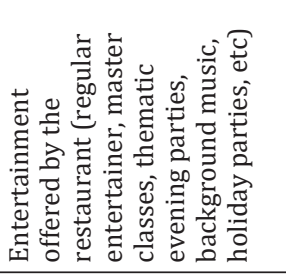 \\
\hline & 0 & n & $\infty$ \\
\hline
\end{tabular}




\begin{tabular}{|c|c|c|c|}
\hline 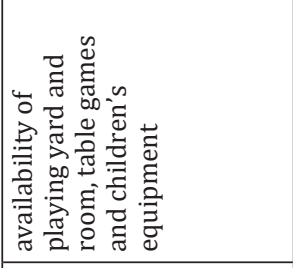 & 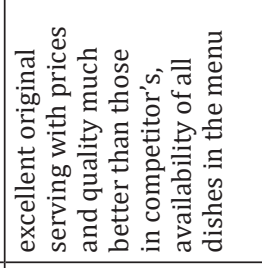 & 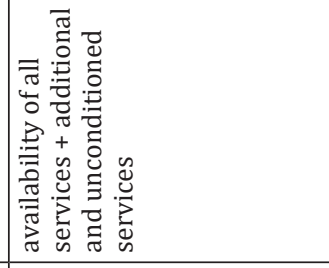 & 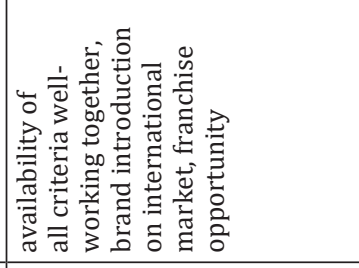 \\
\hline 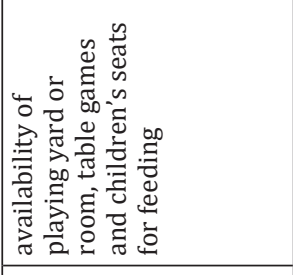 & 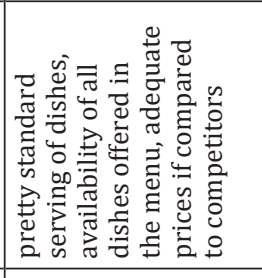 & 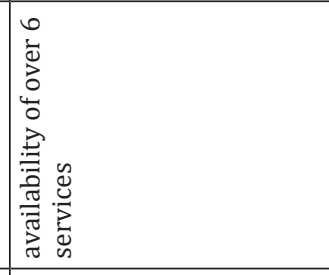 & 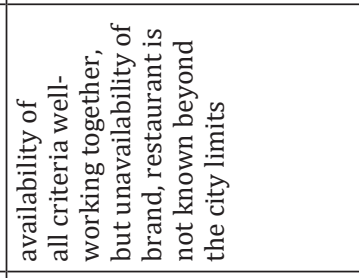 \\
\hline 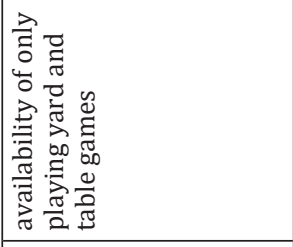 & 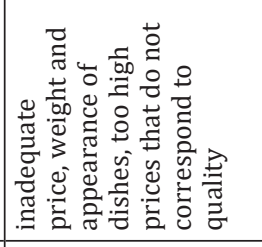 & 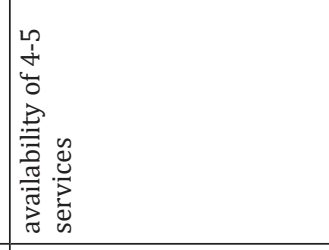 & 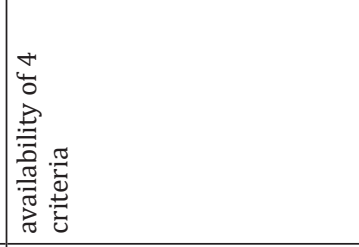 \\
\hline 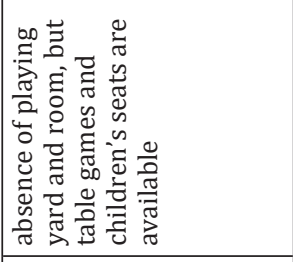 & 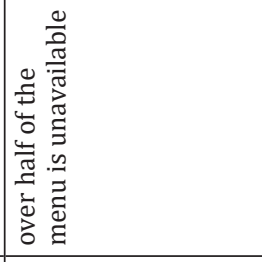 & 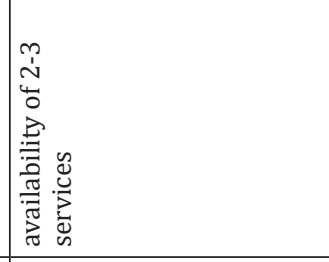 & 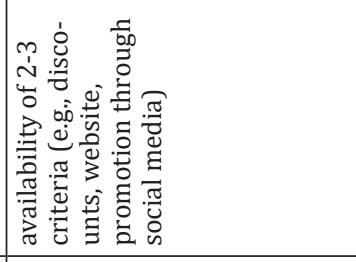 \\
\hline 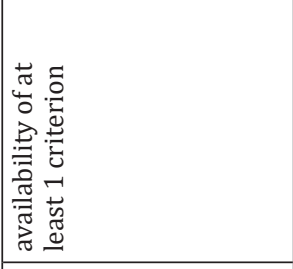 & 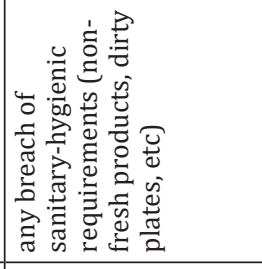 & 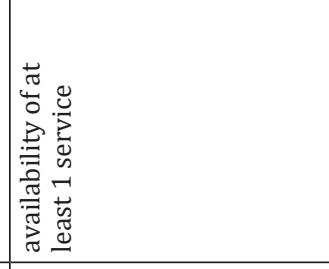 & 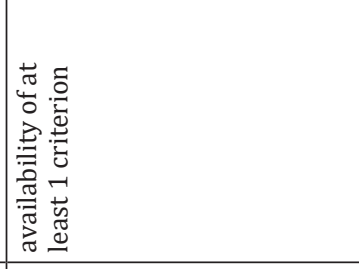 \\
\hline 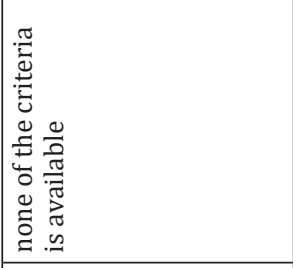 & 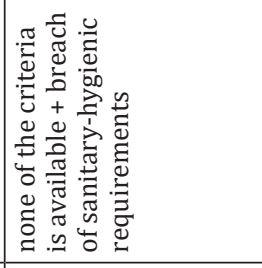 & 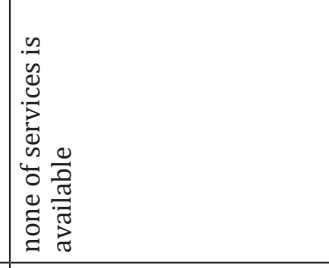 & 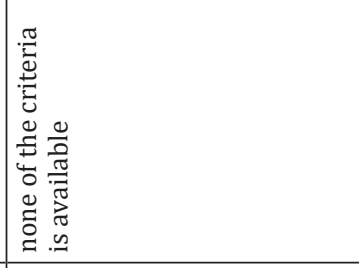 \\
\hline 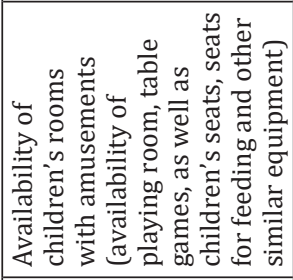 & 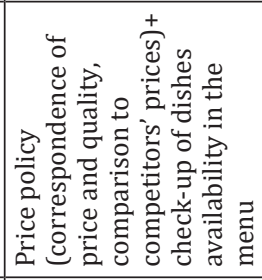 & 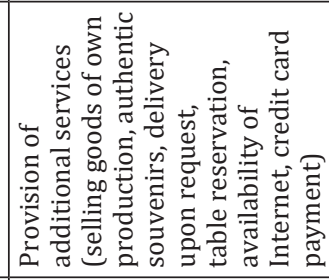 & 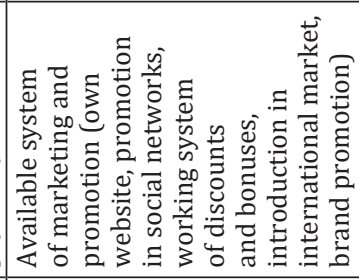 \\
\hline$\sigma$ & 9 & $\exists$ & $\underset{7}{\nearrow}$ \\
\hline
\end{tabular}


The number of points gained by the restaurant is divided into a reference value - maximum points that can be gained by the establishment under the criteria of competitiveness thus establishing the degree of competitiveness of this or that specific restaurant (Androsova et al., 2010):

$$
K_{\mathrm{i}}=\frac{\sum_{1}^{12} x_{i}^{\varnothing}}{\mathrm{x}_{\max }},
$$

where Ki stands for general degree of restaurant's competitiveness;

$\mathrm{Xi} \Phi$ is actual total number of points under criteria of competitiveness; and

Xmax - total maxum number of points under criteria of competitiveness (reference value).

The closer the restaurants' degree of competitiveness to 1 , the more competitive it is.

\section{PERSPECTIVES AND CHALLENGES FOR THE DEVELOPMENT OF COMPETITIVE POSITIONS OF CHERNIVTSI RESTAURANTS}

Ukraine possesses huge potential for the development of establishments of public catering with restaurants having the biggest share. Essentially sensitive to economic situation, currency exchange rate fluctuations and social factors, restaurant market is among the most dynamic markets in Ukraine (Piatnytska, 2007). The last two years witnessed the market's efforts for active restoration after the political and economic crises that took place in 2014-2015. On the whole, the aforesaid period witnessed nearly 5,000 establishments of public catering vanishing from the scene. According to assessments conducted by the RestConsulting, nearly 1,500 restaurants disappeared, having not overcome the crisis and a bit over 4,000 were left in the occupied Crimea and the zone of Anti-Terrorist Operation.

The overall capacity of the Ukrainian restaurant market is assessed by analysts to amount to UAH30 milliard, while the total number of establishments (over 15,000) reached the figures of pre-crisis 2013 (with no restaurants of the Crimea and those left in the ATO zone included).

The same as it is in the whole world, strongest competition is observed in the sphere of hotel/restaurant industry in Ukraine. The market is exceptionally aggressive with supply exceeding the demand, and restaurants therefore encounter difficulties with advocating their interests. Situation is only cured by way of improving the quality of serving and offering special services, but small entities are made to survive and work at a loss. One more problem of restaurant business in Ukraine is that the cost shall be recovered within the next 5-6 years, and few small entities would live so long because the risks were not thoroughly calculated, right direction was not guessed by the owner, or clients have chosen the competitor's establishment for this or that reason.

As regards administrative regions of West Ukraine, Chernivtsi Region attracts tourists with nature-landscape and ethno-cultural specificities; similar system of life stereotypes and values; borderline political and transport-geographical disposition, etc. As of 2017, almost 25\% of registered entrepreneurships were active in the area of trade and services. The city citizens and guests' demands for goods and food products are satisfied in 20 trade centres and supermarkets, over 600 establishments of 
restaurant business, nearly 250 objects of wholesale trade and over 1,500 objects of retail trade of different forms of ownership [accessed 16 April 2018].

The biggest number of restaurant business establishments is found in Chernivtsi where 240 such entities can seat 25,700 people at a time. Among these, there are 60 restaurants offering the whole spectrum of traditional courses from all over the world, namely Ukraine, Europe (French, Rumanian, Greek, Italian cuisines), Asia (Japanese, Korean, Indian, Chinese), as well as other national and mixed cuisines. Among these we can place emphasis on such restaurants such as Knaus - a part of Germany in the heart of Chernivtsi; Kosher Organic - the only kosher food establishment in the city where one would enjoy Jewish national dishes prepared according to ancient recipes; La multi ani worthily represents Moldavian cuisine, while Bucuresti - Romanian. Another 3 restaurants in Chernivtsi fittingly represent Indian (Bindi), Chinese (Kyoto), and Georgian (Khinkali) cuisines, etc.

Table 3. Point-based assessment of Chernivtsi restaurants

\begin{tabular}{|c|c|c|c|c|c|c|c|c|c|c|c|c|c|c|}
\hline \multirow{2}{*}{ No. } & \multirow{2}{*}{ Restaurant } & \multicolumn{12}{|c|}{ Criterion assessment } & \multirow{2}{*}{$\begin{array}{l}\text { Total } \\
\text { points }\end{array}$} \\
\hline & & 1 & 2 & 3 & 4 & 5 & 6 & 7 & 8 & 9 & 10 & 11 & 12 & \\
\hline 1. & Habsburg & 5 & 4 & 2 & 3 & 4 & 4 & 4 & 2 & 1 & 5 & 1 & 2 & 37 \\
\hline 2 & Chernivtsi & 5 & 2 & 5 & 5 & 5 & 5 & 5 & 4 & 0 & 4 & 5 & 2 & 47 \\
\hline 3 & Kyiv & 5 & 4 & 4 & 3 & 3 & 3 & 2 & 2 & 0 & 4 & 2 & 0 & 32 \\
\hline 4 & Allure Inn & 5 & 4 & 3 & 4 & 5 & 5 & 5 & 5 & 5 & 5 & 5 & 4 & 55 \\
\hline 5 & Duke's Estate & 4 & 1 & 5 & 5 & 5 & 5 & 5 & 4 & 5 & 5 & 3 & 2 & 51 \\
\hline 6 & Khinkali & 5 & 4 & 2 & 3 & 5 & 5 & 4 & 1 & 0 & 5 & 5 & 4 & 43 \\
\hline 7 & Rita Steinberg & 5 & 5 & 2 & 3 & 5 & 5 & 4 & 4 & 0 & 5 & 2 & 0 & 40 \\
\hline 8 & Palazzo & 4 & 0 & 3 & 4 & 5 & 5 & 3 & 2 & 4 & 5 & 2 & 2 & 39 \\
\hline 9 & Waterfall & 4 & 0 & 1 & 4 & 4 & 4 & 2 & 2 & 0 & 4 & 2 & 0 & 27 \\
\hline 10 & Kwinto & 5 & 5 & 1 & 5 & 5 & 5 & 5 & 4 & 1 & 5 & 2 & 4 & 47 \\
\hline 11 & Bruno & 5 & 5 & 1 & 4 & 4 & 3 & 4 & 0 & 0 & 4 & 2 & 2 & 34 \\
\hline 12 & Seigniorial Distillery & 5 & 5 & 1 & 3 & 5 & 5 & 5 & 5 & 0 & 5 & 5 & 5 & 51 \\
\hline 13 & Bucuresti & 5 & 5 & 1 & 5 & 5 & 5 & 4 & 4 & 1 & 5 & 5 & 5 & 50 \\
\hline 14 & Chernivtsi Townswoman & 5 & 5 & 1 & 3 & 0 & 3 & 1 & 2 & 0 & 3 & 1 & 0 & 24 \\
\hline 15 & Kyoto & 5 & 5 & 1 & 4 & 5 & 5 & 5 & 1 & 0 & 5 & 4 & 4 & 44 \\
\hline 16 & Zone Secret Kitchen & 5 & 5 & 3 & 4 & 5 & 5 & 5 & 4 & 2 & 5 & 1 & 3 & 47 \\
\hline 17 & Bartka & 5 & 0 & 3 & 4 & 5 & 5 & 5 & 5 & 5 & 5 & 5 & 4 & 51 \\
\hline 18 & Di Bocca & 5 & 4 & 3 & 3 & 5 & 5 & 5 & 4 & 0 & 5 & 4 & 4 & 47 \\
\hline 19 & Beijing & 5 & 2 & 1 & 3 & 5 & 5 & 4 & 2 & 0 & 5 & 5 & 3 & 40 \\
\hline 20 & Charm & 5 & 2 & 3 & 4 & 4 & 1 & 2 & 0 & 2 & 0 & 4 & 1 & 28 \\
\hline 21 & Sorbonne & 5 & 5 & 3 & 5 & 5 & 5 & 5 & 2 & 0 & 5 & 2 & 4 & 46 \\
\hline 22 & Li Vuar & 5 & 0 & 3 & 4 & 3 & 3 & 3 & 2 & 0 & 4 & 1 & 2 & 30 \\
\hline 23 & Diana & 4 & 0 & 3 & 3 & 4 & 5 & 2 & 2 & 0 & 5 & 2 & 2 & 32 \\
\hline 24 & S.O.D.A. & 4 & 0 & 3 & 5 & 5 & 5 & 5 & 1 & 0 & 5 & 2 & 2 & 37 \\
\hline 25 & Day and Night & 4 & 1 & 5 & 4 & 5 & 5 & 4 & 4 & 0 & 5 & 2 & 2 & 41 \\
\hline 26 & Guest House & 4 & 0 & 5 & 5 & 4 & 4 & 4 & 3 & 4 & 4 & 2 & 2 & 41 \\
\hline 27 & Premiere & 4 & 0 & 4 & 4 & 5 & 5 & 4 & 2 & 0 & 5 & 3 & 2 & 38 \\
\hline 28 & Gopachok & 5 & 2 & 2 & 4 & 5 & 5 & 5 & 1 & 0 & 5 & 4 & 3 & 41 \\
\hline 29 & Winston Hall & 5 & 2 & 4 & 5 & 5 & 5 & 5 & 3 & 0 & 5 & 3 & 2 & 44 \\
\hline 30 & Brizole & 4 & 0 & 4 & 5 & 4 & 5 & 3 & 2 & 4 & 5 & 2 & 2 & 40 \\
\hline
\end{tabular}




\begin{tabular}{|c|c|c|c|c|c|c|c|c|c|c|c|c|c|c|}
\hline 31 & Golden Pheasant & 4 & 0 & 3 & 4 & 4 & 4 & 3 & 2 & 0 & 4 & 2 & 2 & 32 \\
\hline 32 & Coziness & 3 & 0 & 3 & 4 & 4 & 5 & 2 & 3 & 0 & 4 & 3 & 2 & 34 \\
\hline 33 & Delta & 4 & 1 & 4 & 3 & 4 & 5 & 3 & 3 & 0 & 5 & 2 & 2 & 36 \\
\hline 34 & Versaille & 3 & 0 & 4 & 5 & 5 & 5 & 3 & 2 & 0 & 5 & 2 & 2 & 36 \\
\hline 35 & Park Tower & 4 & 2 & 4 & 5 & 5 & 5 & 2 & 2 & 0 & 5 & 2 & 2 & 38 \\
\hline 36 & Baron Gartenberg & 3 & 0 & 5 & 5 & 4 & 5 & 5 & 3 & 1 & 5 & 3 & 2 & 42 \\
\hline 37 & George Palace & 4 & 4 & 5 & 5 & 5 & 5 & 4 & 2 & 1 & 5 & 2 & 2 & 44 \\
\hline 38 & Rhoxolana & 3 & 0 & 4 & 4 & 5 & 5 & 2 & 2 & 1 & 5 & 2 & 2 & 37 \\
\hline 39 & Babylon & 5 & 4 & 4 & 3 & 3 & 5 & 3 & 2 & 0 & 5 & 2 & 2 & 38 \\
\hline 40 & Boulevard & 4 & 0 & 3 & 1 & 4 & 4 & 2 & 2 & 0 & 4 & 2 & 2 & 31 \\
\hline 41 & Cleopatra & 4 & 0 & 4 & 5 & 5 & 5 & 4 & 3 & 5 & 5 & 4 & 4 & 48 \\
\hline 42 & Knaus & 5 & 4 & 3 & 5 & 5 & 5 & 5 & 3 & 0 & 5 & 3 & 5 & 48 \\
\hline 43 & Fortress & 5 & 0 & 4 & 4 & 3 & 4 & 2 & 2 & 5 & 4 & 2 & 2 & 37 \\
\hline 44 & Coral & 3 & 0 & 4 & 3 & 3 & 4 & 2 & 2 & 0 & 4 & 2 & 2 & 27 \\
\hline 45 & Maestro & 4 & 4 & 5 & 5 & 5 & 5 & 2 & 2 & 0 & 5 & 3 & 2 & 42 \\
\hline 46 & Faberge & 3 & 0 & 4 & 3 & 4 & 4 & 2 & 2 & 5 & 4 & 3 & 2 & 36 \\
\hline 47 & Andinna & 4 & 0 & 4 & 4 & 4 & 5 & 2 & 2 & 0 & 5 & 2 & 2 & 34 \\
\hline 48 & Wheel & 5 & 5 & 1 & 3 & 5 & 5 & 5 & 2 & 0 & 5 & 4 & 3 & 43 \\
\hline 49 & Beluga Stafood & 5 & 5 & 4 & 3 & 5 & 5 & 4 & 2 & 0 & 5 & 4 & 3 & 45 \\
\hline 50 & Keiser & 5 & 0 & 3 & 5 & 5 & 5 & 3 & 2 & 0 & 5 & 2 & 2 & 37 \\
\hline 51 & La multi ani & 4 & 2 & 3 & 3 & 3 & 5 & 3 & 3 & 0 & 5 & 3 & 2 & 36 \\
\hline 52 & Aristocrat & 3 & 0 & 5 & 5 & 5 & 5 & 4 & 2 & 0 & 5 & 3 & 4 & 41 \\
\hline 53 & Checheri & 4 & 1 & 4 & 3 & 3 & 5 & 2 & 2 & 0 & 5 & 2 & 2 & 33 \\
\hline 54 & Bindi & 5 & 1 & 3 & 2 & 3 & 5 & 2 & 0 & 0 & 4 & 2 & 2 & 29 \\
\hline 55 & Frigate & 4 & 0 & 4 & 3 & 4 & 5 & 2 & 2 & 0 & 5 & 2 & 2 & 33 \\
\hline 56 & Picnic & 4 & 0 & 4 & 5 & 5 & 5 & 3 & 3 & 0 & 5 & 2 & 2 & 38 \\
\hline 57 & Idyllic Frog & 5 & 4 & 3 & 3 & 5 & 5 & 2 & 1 & 0 & 5 & 2 & 2 & 37 \\
\hline 58 & $\begin{array}{l}\text { Kosher Organic } \\
\text { Restaurant }\end{array}$ & 5 & 2 & 3 & 4 & 5 & 5 & 2 & 2 & 0 & 5 & 3 & 2 & 38 \\
\hline 59 & Seigniorial Consolation & 4 & 0 & 3 & 4 & 5 & 5 & 2 & 2 & 0 & 5 & 2 & 2 & 34 \\
\hline 60 & Dayana & 4 & 0 & 4 & 3 & 4 & 4 & 2 & 2 & 0 & 5 & 2 & 2 & 32 \\
\hline
\end{tabular}

Beside everyday serving, these public catering establishments specialise in organisation of different holidays and entertainments such as birthdays, weddings, corporative parties, school-leaving parties, romantic meetings, etc.

To help study the competitiveness among restaurants of Chernivtsi Region, we chose sixty that differ in their geographical disposition, style, cuisine, etc (Table 3).

The aforementioned restaurants essentially differ in their seating capacities. The least share (7\%) can seat up to 50 visitors (Zone Secret Kitchen, Habsburg, Boulevard, Beluga Stafood), while $17 \%$ are capable to have 200 guests at a time (Palazzo, Baron Gartenberg, Aristocrat). Small seating capacity restaurants are predominantly regular public catering establishments and capacious function as banquet-day restaurants.

We have analysed the competitiveness of 60 restaurants of Chernivtsi. All entities received different number of points which allowed for their grouping into leaders, main body, runners up, and outsiders (Table 4). 
Table 4. Competitiveness of Chernivtsi restaurant groups

\begin{tabular}{|l|l|l|c|}
\hline Restaurant groups & \multicolumn{1}{|c|}{ Total points } & \multicolumn{1}{|c|}{ Top 5 restaurants } & $\begin{array}{c}\text { Total } \\
\text { entities }\end{array}$ \\
\hline leaders & more than 45 & $\begin{array}{l}\text { Duke's Estate, Seigniorial Distillery, Zone Secret } \\
\text { Kitchen, Di Bocca, Bartka }\end{array}$ & 12 \\
\hline main body & $36-45$ & Kwinto, Habsburg, Khinkali, Palazzo, S.O.D.A & 31 \\
\hline runners up & $31-35$ & $\begin{array}{l}\text { Andinna, Checheri, Seigniorial Consolation, Boulevard, } \\
\text { Golden Pheasant }\end{array}$ & 11 \\
\hline outsiders & less than 30 & $\begin{array}{l}\text { Chernivtsi Townswoman, Waterfall, Coral, Bindi, } \\
\text { Charm }\end{array}$ & 6 \\
\hline
\end{tabular}

Source: authors' own work

Restaurants-leaders (12 entities) are distinctive for high rate of competitiveness (45-55 points). Average competitiveness is characteristic for 31 restaurants that comprise the main body (52\% out of all restaurants in Chernivtsi that gained 36-45 points). Below-average rating is possessed by 11 restaurants that take the third place in the table. Low competitiveness (less than 30 points) is shown by 4 entities, or outsiders that make $7 \%$ out of all study objects. All the aforesaid figures prove the predominance of average-competitive restaurants in Chernivtsi.

Proceeding from 12 afore-mentioned criteria of competitiveness we may define the mean value for each of these and construct a polygon of competitiveness to help visualize and compare its essential parameters (criteria) (see Figure 1).

Restaurant's cuisine and adequate quality/price proportion are among the most essential factors of competitiveness, since the tastiness of dishes does determine whether or not the guest satisfied his gastronomic demands. Location is another important factor that effects on the figures of establishment's attendance. The majority of restaurants in Chernivtsi have found their placement in the downtown which is a good preference when compared to those on the periphery. In a perfect world, the restaurant should be easily accessed; it should attract by a noticeable signboard and convenient work time; the interior should be atmospheric to provide for guest's mood, comfort and final impression of the visit; entertainments should allow for his peaceful rest, have fun and unique emotions. Service level is a factor that effects on the guest's impression, either bad or such that would make him wish to visit the restaurant once more. Closeness to historic-cultural or natural monuments would add to restaurant's attractiveness at the expense of tourism attractions. Unfortunately, such additional services as children's rooms and marketing that would place restaurants on a higher level are still generally ignored.

Having analysed the study results, we can conclude the bigger number of points was gained by restaurants located in the downtown, having an exquisite cuisine, providing for parking lots and offering wide assortment of various services.

Having analysed the assessment results, we may conclude that the biggest number of points is gained by those restaurants that accumulated bigger flows of guests, such fact once again confirming and proving the correctness of chosen methods.

The assessment of restaurant competitiveness will allow for disclosure of the best establishments, as well as for substantiation of further steps in the activity of those restaurants that show the least competitiveness so that they could continue to be active on the market, become profitable and satisfied the consumers' demands. Such steps 
Figure 1. Polygon of Chernivtsi restaurants' competitiveness

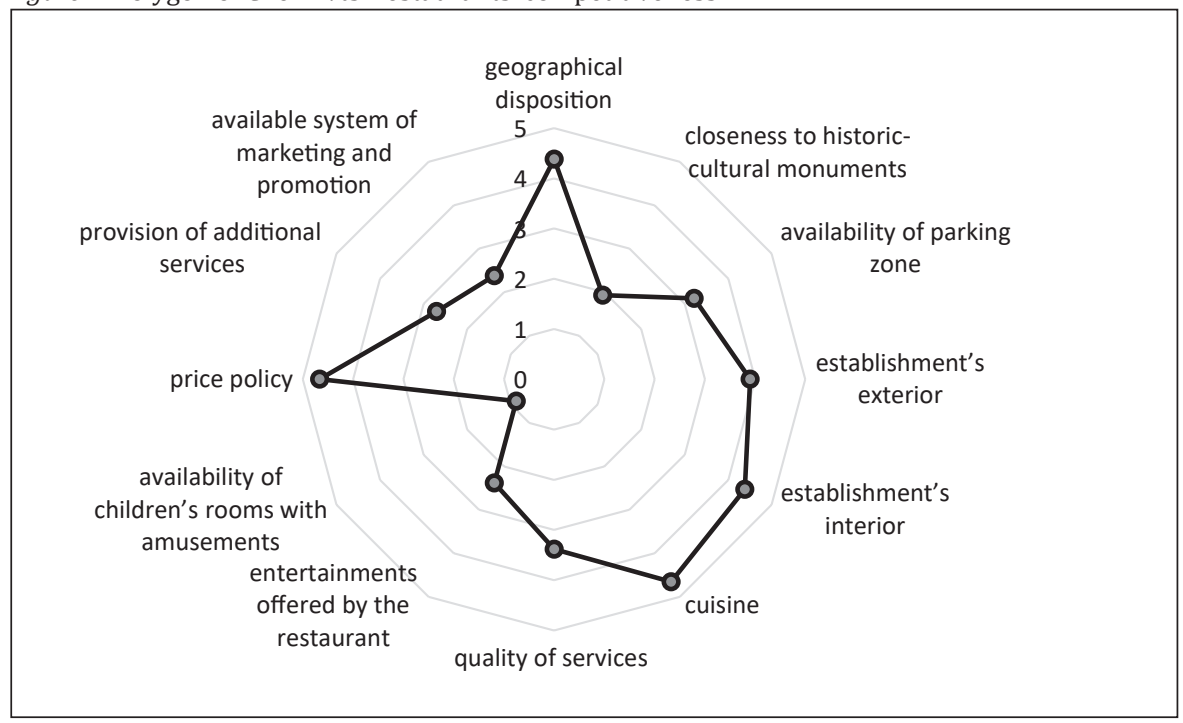

Source: authors' own work

would include efficient use of the potential; finding position with the assortment and its broadening, up-to-date interpretation of serving; development and implementation of new forms of serving; establishment of the scope of services to be offered to guests on the basis of study of their stories; raise of personnel's competitiveness; decrease of restaurant costs; solicit customers of competitor companies through advertising, etc.

Having generalised theoretical and practical studies, we may assert that the aforesaid scheme can serve as a basis for the assessment of restaurant competitiveness. In each single case it can be added with additional parameters and characteristics that would reveal the individuality of this or that establishment. We believe that the assessment is a dynamic concept where the state of the object does not only depend on its current position but on the same in the past and in the future.

\section{CONCLUSIONS}

Restaurant business is among the most important components in the industry of hospitality representing one the most widespread types of small business today. The public catering establishments are therefore in the state of continuous competition trying to preserve them in the market, find new and maintain old consumers of their goods and services. Restaurant business in Chernivtsi Region is, on the one side, a rather profitable and investment-attractive type of entrepreneurial activity; on the other side, it involves high level of competition which requires continuous growth and improvement.

Having analysed the resulting points of our assessment we cannot but come to a conclusion that the highest ranks are possessed by those restaurants of Chernivtsi that show excellent parameters of competitiveness. These are those restaurants where the highest flow of customers is observed thus confirming our methodology. To have a clear vision of the efficiency of restaurant business, one should continuously assess its competitiveness. It would allow for understanding of restaurant's place in the market, 
its advantages and shortages if compared to competitors, as well as would serve as a push towards the choice of futures strategic development.

The competitiveness of the aforesaid restaurants in the first place depends on their managers who should optimise the efficiency of every investment into resources, introduce innovative technologies, analyse world experience of known restaurant networks, concentrate on continuous satisfaction of consumer needs, intensely involve marketing policies, provide for necessary conditions for successful realisation of products, use encouragements (bonus programs, discounts, actions, drawing, etc), monitor and analyse situation on the market in present-day conditions of economic management.

\section{References}

Androsova, T.V., Vlasova, N.O., Mykhailova, H.V,. Kruglova, O.A. (2010). Otsinka Konkurentospromozhnosti Pidpryiemstv Restorannoho Hospodarstva [Assessment of competitiveness in establishments of restaurant business]. State University of Catering and Trade. Kharkiv [In Ukrainian].

Covin, J. G., Slevin, D.P. (1990). New venture strategic posture, structure, and performance: an industry life cycle analysis. Journal of Business Venturing, 5(2), 123-135. doi: $10.1002 \mathrm{mj} .4250100107$

Dolzhanskyi, I.Z. (2006). Konkurentospromozhnist pidpryiemstva: navchalnyi posibnyk [Competitiveness of enterprises: a textbook]. Kyiv: Tsentr navchalnoi literatury. [In Ukrainian]

Gorynia M. (2002). Schemat analityczny - aspekt konceptualny i metodyczny [Analytical scheme for adaptive research gaps conceptual and methodological aspects]. Competitive gap at the enterprise level and the Polish accession to the European Union. Poznań: University of Economics in Poznan.

Ivanov, Yu. B. (2008). Konkurentni perevahy pidpryiemstva: otsinka, formuvannia ta rozvytok [Competitive advantages of the enterprise: assessment, formation and development]. Kharkiv: INZhEK. [In Ukrainian]

Lamben Zhan-Zhak. (2004). Menedzhment, oryentyrovannyi na rynok [Market oriented management]. SPb.: Pyter. [In Russian]

Nechaiuk, L. I. (2009). Hotelno-restorannyibiznes: Menedzhment [Hotel and restaurant business: management]. Kyiv: Tsentrnavch. [In Ukrainian]

Omar, M. S., Ariffin, H. F., \& Ahmad, R. (2016). Service quality, customers' satisfaction and the moderating effects of gender: A study of Arabic restaurants. Procedia - Social and Behavioral Sciences, 224, 384-392. doi: 10.1016/j.sbspro.2016.05.393

Ormanidhi, O., Siringa, O. (2008). Porter's Model of generic competitive strategies: An insightful and convenient approach to firms' analysis. Business Economics, 43(3): 55-64. doi: $10.2145 / 20080305$

Piatnytska, H.T. (2007). Restoranne hospodarstvo Ukrainy: rynkovi transformatsii, innovatsiinyi rozvytok, strukturna pereoriientatsiia [Ukrainian Restaurant Industry: Market Transformations, Innovative Development, Structural Reorientation]. Kyyiv: nats. torh.-ekon. un-t. [In Ukrainian]

Porter, M.E. (1980). Competitive strategy: Techniques for analyzing industries and competitors. New York: Free Press.

Pshenyshniuk, I.O. (2012). Imidzh pidpryiemstva yak metod konkurentnoi borotby [The image of the company as method of competition]. Ekonomika ta derzhava, 5, 19-21. [In Ukrainian]

Stankiewicz, M.J. (2002). Competitiveness of business. Building the competitiveness of enterprises in globalization. Toruń: Dom Organizatora.

Sushko, O.V. (2005). Osoblyvosti ta tendentsii formuvannia rynku restorannoho hospodarstva [Features and trends of formation of restaurant market]. Torhivlia i rynok Ukrainy, 20, 295310. [In Ukrainian] 
Tavitiyaman, P., Qu, H., Zhang, H. (2011). The impact of industry force factors on resource competitive strategies and hotel performance. International Journal of Hospitality Management, 30, 648-657.

Voon, B.H. (2012). Role of service environment for restaurants: the youth customers' perspective. Procedia-Social and Behavioral Sciences, 38, 388-395.

Tetiana Yemchuk, PhD in geographical sciences, assistant professor in the Department of Economic Geography and Ecological Management Chernivtsi Yuriy Fedkovych National University. Scientific/research interests and publications: economic geography and tourism inclusive of spatial tourism management and local development, spatial organisation of tourism and recreation, spatial research of recreation resources, and assessment of tourism resources.

ORCID: 0000-0002-3533-9587

\section{Address:}

Chernivtsi Yurii Fedkovych National University

Department of Economic Geography and Ecological Management

Kotsubinsky Str., 2, 58012 Chernivtsi, Ukraine

e-mail: iemchuktania17@gmail.com

Oksana Arpul, PhD in engineering science, associate professor in the Department of Hotel and Restaurant Business, Faculty of Hotel, Restaurant and Tourism Business, National University of Food Technologies. Scientific/research interests and publications: hotel and restaurant enterprises inclusive of innovations in the field of hotel and restaurant enterprises, technical and economic provision of areas of hotel and restaurant establishments, spatial organisation of hotels and restaurants.

ORCID: 0000-0003-3350-3790

\section{Address:}

National University of Food Technologies

Department of Hotel and Restaurant Business

Volodymyrska Str., 68, 01601 Kyiv, Ukraine

e-mail: kseniya.arpul@gmail.com 